\title{
Batch removal of aqueous nitrate ions using an effective nano- biocomposite
}

\author{
Sepehri S. *and Nakhjavanimoghaddam M.M. \\ Agricultural Engineering Research Institute (AERI), Agricultural Research, Education and Extension Organization (AREEO), P.O. Box \\ 31585-845, Karaj, Iran
}

Received: 15/08/2018, Accepted: 16/10/2018, Available online: 25/10/2018

*to whom all correspondence should be addressed: e-mail: s.sepehri@aeri.ir, sepehri_saloome@yahoo.com https://doi.org/10.30955/gnj.002868

\section{Abstract}

The intent of this research is the investigation of the nitrate reduction from aqueous solution using biomass (pine cone (PC) and PC activated carbon (PCAC)) supported zero valent iron nanoparticles $\left(P C-\mathrm{Fe}^{0}\right.$ and PCAC-Fe ${ }^{0}$. The synthesis of these nano-bio-composites was based on the reduction of ferrous iron with borohydride, in which PC and PCAC acted as porous-based support materials. The structure of the adsorbents was characterized by SEM, XRD, FTIR and BET analysis. The SEM images revealed that $\mathrm{nZVI}$ immobilized on PC-Fe ${ }^{0}$ and PCAC-Fe ${ }^{0}$ were spherical and uniformly dispersed on the surface of the stabilizers. Batch experiments indicated that the nitrate removal efficiency decreased with the increase in the initial nitrate concentration and initial $\mathrm{pH}$, but increased with the increase in the sorbent dosage and temperature. The maximum adsorption capacities of $\mathrm{PC}-\mathrm{Fe}^{0}$ and $\mathrm{PCAC}-\mathrm{Fe}^{0}$ for nitrate were 18.16 and $22.30(\mathrm{mg} / \mathrm{g})$, respectively. The nitrogen mass balance calculations revealed that zero valent iron nanoparticles in both PC-Fe ${ }^{0}$ and PCAC-Fe ${ }^{0}$ beads could generally reduce nitrate into ammonium, and nitrite usually was occurred as intermediate. Subsequently, PCAC-Fe ${ }^{0}$ absorbs completely un-wanted ammonium, while $\mathrm{PC}-\mathrm{Fe}^{0}$ releases little ammonium in the solution.

Keywords: Bio activated carbon; kinetic modeling; nanoscale zero-valent iron particles; redox reaction; sorption isotherm.

\section{Introduction}

High nitrate concentration has become a serious common water quality problem in agricultural regions. The sources of nitrogen compounds accumulation in the environment include industrial wastewaters and municipal discharges, nitrogenous fertilizers, the unreasonable disposal of animal wastes, septic systems, and atmospheric deposition from nitrogen oxide emission (Driscoll et al., 2003). The nitrate has high chemical stability, especially at low concentrations, which can cause environmental problems, such as, eutrophication. In addition, groundwater is a considerable source of drinking water.
Continuous uptake of nitrate and nitrite via drinking water will lead to several health treats to human including, cancers and methemoglobinemia (Kim et al., 2015). Many technologies are available for treating nitrate from water, such as, ion exchange, reverse osmosis, adsorption, biological and chemical reductions (Tada et al., 2004). Although, these techniques are effective in removing nitrate from water, most of them are limited in the factual application for the remediation.

In recent years, nanoscale Zero-Valent Iron (nZVI) particles has been widely studied as an environmentally friendly strong reducing agent. Due to its small size, high specific surface area, suitable redox potentials and faster and more complete reactions (comparison with other $\mathrm{ZVI}$ materials), $\mathrm{nZVI}(\mathrm{nZVI}<100 \mathrm{~nm})$ is a promising alternative for water contaminants removal (Mukherjee et al., 2016). Several studies reported the efficiency of $\mathrm{nZVI}$ for the removal of a variety of contaminants including heavy metals (Hou et al., 2008), aromatic compounds (Lomnicki and Dellinger, 2003), pesticides (Joo and Zhao, 2008) and dyes (Lin et al., 2008). However, iron nanoparticles expose vigorous propensity to agglomerate into micron or larger solid particles. This is unavoidable because of the high surface energy, intrinsic magnetic interaction and direct interparticle interactions, such as, van der waals forces. Furthermore, the separation of non-supported iron nanoparticles from the aqueous phase is still a difficult undesirable task (Wang et al., 2008). Agglomeration reduces the effective surface area and thereby decreasing both particle reactivity and removal efficiency (Pan et al., 2010). Recently, iron nanoparticles have been modified to prevent their aggregation and improve their removal abilities, such as, mechanical strength, stability, reactivity and flexibility (Zhao et al., 2016). It was reported that the chemical reduction of an aqueous iron salt with borohydride in the presence of porous supporting materials, can decrease the aggregation of iron nanoparticles (Shi et al., 2011). This method has many advantages, such as, safety, facility, cost-effective, and simplicity. Nano-ZVI stabilization on supporting material 
allows direct contact with the contaminant, reduces the electron path from the nano-ZVI to the target contaminant and increases nano-ZVI reactivity (Bossa et al., 2017). To prevent the aggregation of nanoparticles, various stabilizers have been found effective for stabilizing nZVI including polymers (Li et al., 2011a), nanostructure carbons and surfactant (Sun and Zeng, 2002). Huang et al. (2016) reported that sodium alginate (SA)-modified nanoscale zero-valent iron (NZVI), play a constructive role in the remediation of cadmium contaminated river sediments (Huang et al., 2016). Nanoscale zero valent iron particles stabilized by epichlorohydrin/chitosan (ECH-CS-nZVI) beads have been reported to increase their dispersibility and stability. A removal rate of $\mathrm{Cr}$ (VI) using ECH-CS-nZVI beads could be maintained as high as $76.6 \%$ and $48.2 \%$ on the second and third runs, respectively, which hinted that ECH-CS-nZVI beads could be regenerated (Liu et al., 2012). The study of Wang et al. (2015) suggested that hydroxyethyl cellulose and hydroxypropylmethyl cellulose dispersed NZVI can be utilized as a promising modified nano-material for degradation of dye wastewater (Wang et al., 2015). $\mathrm{Li}$ et al. (2010) investigated $\mathrm{Cr}$ (VI) removal by Montmorillonite and hexadecyl trimethylammonium modified montmorillonite (HDTMA-Mont) supported iron nano-particles. They reported that the presence of organo-montmorillonite apparently decreased the extent of aggregation and the size of the iron particles. In contact with $\mathrm{Cr}(\mathrm{VI})$, the reduction of $\mathrm{Cr}(\mathrm{VI})$ was highest with HDTMA-Mont/iron particles, followed by Mont/iron particles and free iron nanoparticles (Li et al., 2010). In another study, Shi et al. (2011) reported that bentonite-supported nanoscale zero-valent iron had a Specific Surface Area (SSA) of $39.94\left(\mathrm{~m}^{2} \mathrm{~g}^{-1}\right)$, while the SSAs of $\mathrm{nZVI}$ and bentonite were 54.04 and $6.03\left(\mathrm{~m}^{2} \mathrm{~g}^{-1}\right)$, respectively (Shi et al., 2011).

In this research, natural materials, which are abundant and environmental-friendly, are used as the supporting materials of iron nanoparticles. Their sorption capacity attracts contaminants to the surface, and thus enhances the efficiency. So, pine cone (PC) and activated carbon prepared from pine cone (PCAC) were used as the supporting materials for $\mathrm{nZVI}$ and then, the removal of nitrate from aqueous solution was investigated using these modified sorbents (PC-Fe ${ }^{0}$ and PCAC-Fe ${ }^{0}$. This paper reports four issues as follows: (1) the synthesis of PC-Fe ${ }^{0}$ and PCAC- $\mathrm{Fe}^{0}$ by the reduction of $\mathrm{Fe}^{2+}$ ions with $\mathrm{NaBH}_{4}$, and the characterization of the modified beads with Scanning Electron Microscopy (SEM), powder X-ray Diffraction (XRD), Fourier Transform Infrared spectroscopy (FTIR), and Brunauer-Emmett-Teller (BET- $\left.\mathrm{N}_{2}\right)$ technology, (2) the comparison of nitrate removal by raw materials, $\mathrm{PC}-\mathrm{Fe}^{0}$ and PCAC- $\mathrm{Fe}^{0}$, (3) the kinetics and isotherm of nitrate reduction by raw materials, $\mathrm{PC}-\mathrm{Fe}^{0}$ and $\mathrm{PCAC}-\mathrm{Fe}^{0}$, and finally, (4) the evaluation of the initial nitrate concentration, sorbent dosage, initial $\mathrm{pH}$, and adsorption temperature effects on the removal process.

\section{Experimental details}

\subsection{Materials and chemicals}

In this study, all the chemicals were reagent grade, and distilled water was used in all preparations. All reagents were listed below, purchased from Merck or Aldrich: Ferrous sulfate heptahydrate $\left(\mathrm{FeSO}_{4} \cdot 7 \mathrm{H} 2_{\mathrm{O}}\right.$, sodium borohydride $\left(\mathrm{NaBH}_{4}\right)$, potassium nitrate $\left(\mathrm{KNO}_{3}\right)$, ethanol, $\mathrm{NaOH}, \mathrm{HCl}$, and phosphoric acid.

\subsection{Preparation of $P C A C, P C-F e^{0}$, and PCAC- Fe}

PC was obtained from Tehran in Iran. After drying at $80^{\circ} \mathrm{C}$ for 24 h, PC was ground and sieved with a 200 mesh screen prior to use in the experiments. Powdered activated carbon was derived by thermal-chemical procedure from the ground PC. Raw materials were impregnated with $85 \mathrm{wt} . \% \mathrm{H}_{3} \mathrm{PO}_{4}$ solution in the weight ratio of 1:3. To produce activated carbon, acid impregnated samples were placed in an electrical heating furnace with inert atmosphere of nitrogen at a flow rate of $25 \mathrm{ml} \mathrm{min}^{-1}$ and heated in two phases. In the first phase, the reactor was heated at a heating rate of $6^{\circ} \mathrm{C}$ $\min ^{-1}$ up to $170{ }^{\circ} \mathrm{C}$ and held at this temperature for $60 \mathrm{~min}$. The second phase included heating with the rate of $8^{\circ} \mathrm{C} \mathrm{min}$ m $^{-1}$ up to $500{ }^{\circ} \mathrm{C}$ and 60 min retention at this temperature. After gradual cooling down to room temperature in a nitrogen gas stream overnight, the final product was repeatedly washed with hot DI water until the $\mathrm{pH}$ of rinsing water reached a value of 7. Finally, PCAC samples were dried at $110{ }^{\circ} \mathrm{C}$ for $24 \mathrm{~h}$ and stored in a desiccator for later use. The synthesis of $\mathrm{PC}^{-\mathrm{Fe}^{0}}$ and PCAC-Fe ${ }^{0}$ was performed according to the borohydride reduction method. In a typical synthesis of $\mathrm{PC}-\mathrm{Fe}^{0}$ and PCAC- $-\mathrm{Fe}^{0}$, a ferrous solution was first prepared by dissolving $\mathrm{FeSO}_{4} .7 \mathrm{H}_{2} \mathrm{O}$ (iron/(bead) mass ratio $1: 1$ ) in a $4 / 1$ (v/v) absolute ethanol/deionized water mixture $(50 \mathrm{~mL})$. The solution was placed into a three-necked open flask. The solution was mixed with $1 \mathrm{~g} \mathrm{PC}$ and PCAC and stirred for $2 \mathrm{~h}$. PC-Fe ${ }^{0}$ and PCAC-Fe ${ }^{0}$ were synthesized in the solution by reducing $\mathrm{Fe}$ (II) to $\mathrm{Fe}^{0}$ using $\mathrm{NaBH}_{4}$ in the presence of PC and PCAC as stabilizers. Then, $55 \mathrm{~mL}$ of freshly prepared aqueous solution containing $2.04 \mathrm{~g}$ of $\mathrm{NaBH}_{4}\left(\mathrm{BH}^{-} / \mathrm{Fe}^{2+}\right.$ molar ratio of 3.0) was added drop-wise into the mixture, while stirring continuously on a magnetic stirrer resulting in formation of black $\mathrm{Fe}^{0}$ nanoparticles and evolution of $\mathrm{H}_{2}$. The whole process was carried out under inert gases flow of $\mathrm{N}_{2}$ to avoid the oxidization of $\mathrm{PC}^{-\mathrm{Fe}^{0}}$ and PCAC- $\mathrm{Fe}^{0}$. The values of experimental parameters such as $\mathrm{pH}$, reaction time, reactant concentrations, titration rate, temperature $\left(25 \pm 0.5{ }^{\circ} \mathrm{C}\right)$, and stirring speed, were maintained constant during the experiment (Uzum et al., 2009). The borohydride reduces the $\mathrm{Fe}$ (II) to $\mathrm{Fe}^{0}$ according to the following reaction ( $\mathrm{Li}$ et al., 2010):

$$
\mathrm{Fe}^{+2}+2 \mathrm{BH}_{4}^{-}+6 \mathrm{H}_{2} \mathrm{O} \rightarrow \mathrm{Fe}^{0}+2 \mathrm{~B}(\mathrm{OH})_{3}+7 \mathrm{H}_{2} \uparrow
$$

The formed suspension was filtered and the black PC-Fe ${ }^{0}$ and PCAC- $\mathrm{Fe}^{0}$ were washed three times with pure ethanol and dried overnight at $75^{\circ} \mathrm{C}$ under vacuum and kept under a $\mathrm{N}_{2}$ atmosphere prior to use (Uzum et al., 2009). Elemental analyses of PC were determined using a 
Costech ECS 4010 Elemental Analyzer. Physical properties and compositions of PC and PCAC were determined according to the literatures. Morphologies and sizes of the particles were observed with SEM using a Hitachi $\mathrm{S}-4160,20.0 \mathrm{kV}$. The SSAs of PC, PCAC, PC-Fe and PCAC-Fe ${ }^{0}$ samples were measured by the BET- $\mathrm{N}_{2}$ method using a Belsorp mini II (BelJapan) instrument. A Philips X'PERTMPD diffractometer, equipped with a graphite-monochromatized ( $\mathrm{Cu}-\mathrm{K} \alpha$ radiation, $\lambda=1.54 \AA$ ) was used to obtain the XRD patterns. All samples were recorded (Haykiri et al., 2010) between 10 and $70^{\circ}$ (20) at a scanning rate of $0.05 \%$ s. The FTIR spectra of the samples were recorded as $\mathrm{KBr}$ pellets in the spectral range $500-4000 \mathrm{~cm}^{-1}$ by a Tensor 27 (Bruker) FTIR spectrometer at room temperature. The concentrations of nitrate and nitrite in the solutions were analyzed based on the guidelines of the $20^{\text {th }}$ edition of the standard methods by means of a UV-Vis spectrophotometer (V-530) (APHA, 1992). At the end of the reaction, the mass of ammonium sorbed on the PC-Fe ${ }^{0}$ and $\mathrm{PCAC}-\mathrm{Fe}^{0}$ was measured by extracting with $1 \mathrm{M} \mathrm{KCl}$ solution and analyzing the extract solution. $\mathrm{NH}_{4}{ }^{+}$concentration in the solutions was analyzed by a steam distillation procedure (Keeney and Nelson, 1982). The $\mathrm{pH}$ of the solutions was adjusted using $0.1 \mathrm{M}$ $\mathrm{HCl} / \mathrm{NaOH}$ using a $\mathrm{pH}$ meter (Metrohm, $827 \mathrm{pH} \mathrm{Lab).}$

\subsection{Batch experiments}

To evaluate the efficiency of produced materials for nitrate removal in the aqueous solution, experiments were conducted using PC, PCAC, PC-Fe ${ }^{0}$ and PCAC-Fe ${ }^{0}$. The aqueous nitrate solutions were prepared by dissolving appropriated amounts of $\mathrm{KNO}_{3}$ in distilled deionized water. To determine the dependence of the removal efficiency on $\mathrm{pH}$ and temperature, the initial $\mathrm{pH}$ values of nitrate solutions and adsorption temperature were varied from 2 to 10 and 25 to $55^{\circ} \mathrm{C}$, respectively. The effect of the adsorbents dosage on nitrate removal efficiency was investigated by applying various amounts of adsorbents

Table 1. Characteristics of PC sample
(2-10 $\left.\mathrm{g} \mathrm{L}^{-1}\right)$. Equilibrium isotherm studies were performed with different initial concentrations of nitrate from 20 to $320\left(\mathrm{mg} \mathrm{L}^{-1}\right)$, while the initial $\mathrm{pH}$ of the solutions were fixed at the $(6 \pm 0.1)$. The kinetic studies were carried out to determine the best fitted kinetic model and equilibrium time of the adsorption. The batch experiments were carried out in $50 \mathrm{ml}$ polyethylene bottles containing $0.1 \mathrm{~g}$ sorbents and $10 \mathrm{~mL}$ of nitrate solutions of desired concentrations and $\mathrm{pH}$ at room temperature $\left(25 \pm 1{ }^{\circ} \mathrm{C}\right)$. All adsorption tests were performed in triplicate. The solutions were mixed on a shaker with an agitation speed of $200 \mathrm{rpm}$ at $25{ }^{\circ} \mathrm{C}$. The samples were collected periodically. At the end of the adsorption period of $24 \mathrm{~h}$, each sample was filtered and the nitrate concentration in the supernatant was analyzed immediately. The removal efficiency (Re\%) and the adsorption capacity $\left(q_{e}\left(\mathrm{mg} \mathrm{g}^{-1}\right)\right)$ of sorbents were calculated as follows:

$$
\begin{aligned}
& \operatorname{Re}(\%)=\frac{C_{0}-C_{e}}{C_{0}} \times 100 \\
& q_{e}=\frac{\left(C_{0}-C_{e}\right) \times V}{m}
\end{aligned}
$$

Where $C_{0}, C_{e}\left(m g ~ L^{-1}\right), m$ and $V$ are the concentrations of nitrate at initial and equilibrium, the mass of sorbent $(\mathrm{g})$, and the volume of the solution (L), respectively.

\section{Results and discussion}

\subsection{Characterization of $P C, P C A C, P C-F e^{0}$, and PCAC-Fe}

The Physico-chemical characteristics and structural components of PC are presented in Table 1. Moreover, important properties of PCAC are summarized in Table 2. The SSAs of PC, PCAC, PC-Fe $e^{0}$ and PCAC-Fe ${ }^{0}$ measured by BET analysis were $6.1,350.8,52.2$, and $870.6\left(\mathrm{~m}^{2} \mathrm{~g}^{-1}\right)$, respectively. Immobilization of zero-valent iron nanoparticles onto PC and PCAC were accompanied by a significant increase in the specific surface areas.

\begin{tabular}{cccccc}
\hline \multicolumn{9}{c}{ Structural components (\%) } & & \\
\hline Cellulose & Holocellulosics & Lignin & Extractives & Ash \\
\hline 29.96 & 20.63 & 44.84 & 4.55 & 1.76 \\
\hline & Physico-chemical characteristics (\%) & & & \\
\hline Ash & Carbon & Oxygen & Hydrogen & Nitrogen \\
\hline 1.76 & 39.65 & 48.63 & 7.74 & 2.11 \\
\hline
\end{tabular}

\begin{tabular}{|c|c|c|c|}
\hline Nitrogen (\%) & Hydrogen (\%) & Ash(\%) & Carbon (\%) \\
\hline 2.96 & 2.03 & 4.17 & 82.45 \\
\hline Oxygen (\%) & $\begin{array}{c}\text { lodine } \\
\text { number } \\
\left(\mathrm{mg} \mathrm{g}^{-1}\right)\end{array}$ & $\begin{array}{l}\text { Bulk density } \\
\left(\mathrm{kg} \mathrm{m}^{-3}\right)\end{array}$ & \\
\hline 8.12 & 780 & 450 & \\
\hline
\end{tabular}

Table 2. Physico-chemical characteristics of PCAC

The morphology of PC and PCAC, and the distribution of $\mathrm{nZVI}$ particles on the surface of $\mathrm{PC}-\mathrm{Fe}^{0}$ and PCAC-Fe before and after reaction with nitrate ions were analyzed using SEM (Figure 1a-1f). PC sample (Figure 1a) is angular, and the grains show non uniform shape with large breakage including straight and arcuate steps and fractured plates. The SEM image of PCAC (Figure 1b) clearly shows that the adsorbent has porous surface, indicating relatively high surface area, and pores of different sizes and shapes can be observed. It can be seen (Figure 1c) that shape of the nZVI particles immobilized on $\mathrm{PC}-\mathrm{Fe}^{0}$ is generally spherical. Measuring the diameters of 100 particles in different regions of a given image grid can be used to quantify the particle size (Wang et al., 2010). In accordance to this method, the particles size ranged from 45 to $110 \mathrm{~nm}$, with a mean particle diameter of 78 $\mathrm{nm}$, and some aggregates are noted. In the case of PCAC$\mathrm{Fe}^{0}$ (Figure 1d), stabilized $\mathrm{nZVI}$ particles have the coreshell structure, clearly discrete and uniformly dispersed on 
the surface of the stabilizer without any obvious aggregation. The diameter of the particles ranged from 25 to $55 \mathrm{~nm}$ with an average size $40 \mathrm{~nm}$. PCAC-Fe ${ }^{0}$ has smaller particle sizes than $\mathrm{PC}-\mathrm{Fe}^{0}$; this might be attributed to the porous structure of the activated carbon. $\mathrm{Fe}^{2+}$ ions were adsorbed on the surface of the activated carbon, and generally situated at inside channel space. These ions were reduced to $\mathrm{Fe}^{0}$ with $\mathrm{NaBH}_{4}$. Therefore, $\mathrm{Fe}^{0}$ ions were dispersed uniformly on the activated carbon surface. This observation is supported by BET surface area of the activated carbon. Similar results have been reported using bentonite and kaolinite supported iron nano particles, which were used to remove $\mathrm{Cr}(\mathrm{VI})$ and $\mathrm{Co}(\mathrm{II})$ from an aqueous solution, respectively (Shi et al., 2011; Uzum et al., 2009).

In contrast, as indicated in Figures $1 \mathrm{e}$ and $1 \mathrm{f}$, the sizes of nZVI particles increase significantly after reacting with nitrate ions. These particles have nearly rectangular shape. This phenomena could be attributed to the formation of iron (hydr)oxides on the surface of the nanoparticles, occurred due to the redox reaction between immobilized nZVI particles and nitrate ions.

The XRD patterns of PC, PCAC, PC-Fe ${ }^{0}$ and PCAC-Fe before and after reacting with nitrate ions are shown in Figure 2. The XRD pattern of PC (Figure 2a), displayed the raw material has a less organized structure with no indication of any specific crystalline structure. The XRD pattern of $\mathrm{PC}-\mathrm{Fe}^{0}$ shows apparent peaks of $\mathrm{Fe}^{0}$ (b2: $2 \theta=44.67^{\circ}$ and b3: $2 \theta=65.03^{\circ}$ ) (Figure 2b). Moreover, this pattern indicates a weak reflection at $2 \theta=33.88^{\circ}$ (b1) corresponding to iron oxide (maghemite). The XRD pattern of $\mathrm{PC}-\mathrm{Fe}^{0}$ after reaction with nitrate (Figure $2 \mathrm{c}$ ) indicated the presence of lepidocrocite (c1: $\mathrm{p}$ - $\mathrm{FeO}(\mathrm{OH})$, $2 \theta=26.9)$, goethite $(c 2: \alpha-\mathrm{FeOOH}, 2 \theta=36.6)$, magnetite (c3: $\left.\mathrm{Fe}_{3} \mathrm{O}_{4}, 2 \theta=47.18\right)$ and maghemite (c4: $\mathrm{\gamma}-\mathrm{Fe}_{2} \mathrm{O}_{3}$, $2 \theta=60.68)$. Figure $2 d$ reveals a peak at $2 \theta=25^{\circ}(\mathrm{d} 1)$ originated from the amorphous structure of carbon (Allaf et al., 2011). According to the XRD results (Figure 2e), PCAC-Fe ${ }^{0}$ before reacting with nitrate ions contained no significant amount of iron oxides. The iron mainly formed in its zero valent $(\alpha-\mathrm{Fe})$ state with major reflections at $2 \theta=44.91^{\circ}(\mathrm{e} 1)$ and $2 \theta=65.19^{\circ}(\mathrm{e} 2)$. These peaks are weakened considerably, and iron oxide signals were detected in the XRD pattern of PCAC-Fe ${ }^{0}$ after reacting with nitrate ions (Figure $2 \mathrm{f}$ ). In this pattern, three peaks at $2 \theta=33.3^{\circ}(\mathrm{f} 1), 35.8^{\circ}(\mathrm{f} 2)$ and $62.9^{\circ}(\mathrm{f3})$ were observed, which were assigned to the characteristic peaks of goethite $(\alpha-\mathrm{FeOOH})$, magnetite $\left(\mathrm{Fe}_{3} \mathrm{O}_{4}\right)$ and maghemite $\left(\alpha-\mathrm{Fe}_{2} \mathrm{O}_{3}\right)$, respectively (Geng et al., 2009).

It is evident that $\mathrm{ZVI}$ nanoparticles were acting as reducing agents, and the redox reaction has occurred between $\mathrm{Fe}^{0}$ and nitrate ions. PC-Fe ${ }^{0}$ and PCAC- $\mathrm{Fe}^{0}$ had typical PC and PCAC structures, respectively, indicated that $P C$ and PCAC frameworks, and their total crystalline structures were not significantly changed after immobilizing ZVI nanoparticles. The calculated particle sizes (diameter) of PC-Fe ${ }^{0}$ and PCAC-Fe ${ }^{0}$ computed by the Scherrer equation (Birks and Friedman, 1946) were found to be 75 and $35 \mathrm{~nm}$, respectively, which were in a good agreement with the sizes determined by SEM images. FTIR technique gives information about the vibrational state of the adsorbed molecules; hence, FT-IR measurements were carried out to identify the stabilization mechanisms. FTIR spectra were recorded in the transmission mode between 500 and $4000 \mathrm{~cm}^{-1}$ for all samples (Figure 3).
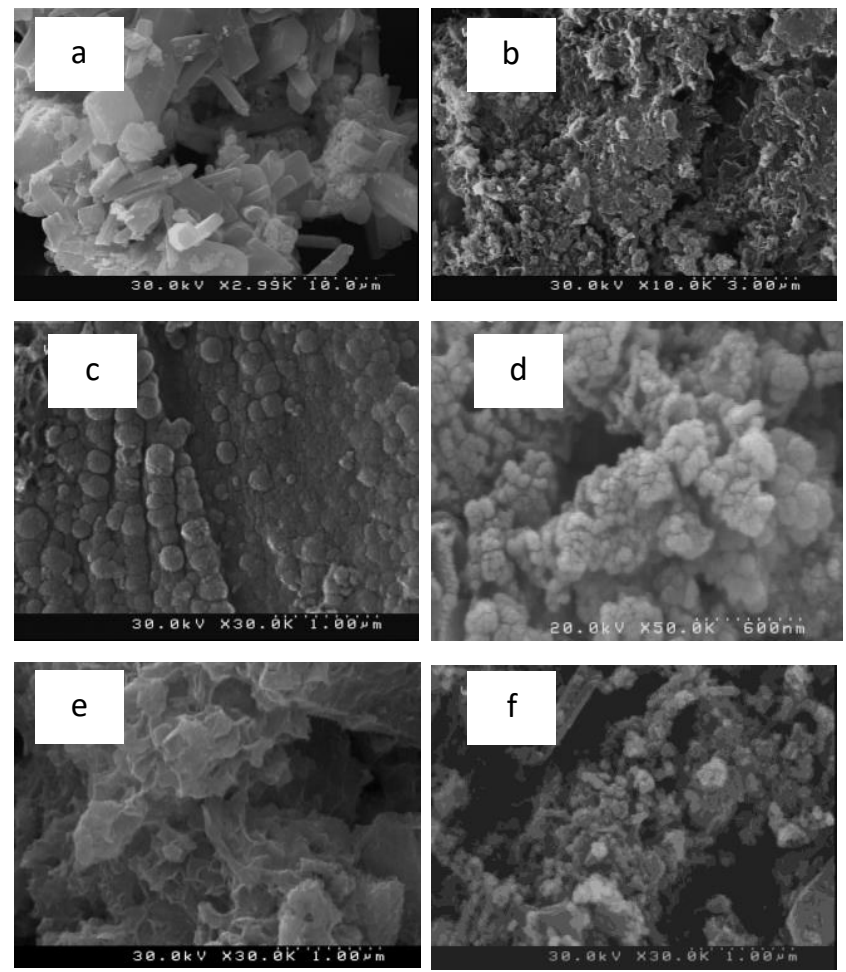

Figure 1. SEM images of: (a) PC, (b) PCAC, (c) PC-Fe ${ }^{0}$ and (d) PCAC-Fe ${ }^{0}$ before reacting with nitrate, (e) PC-Fe ${ }^{0}$ and (f) PCAC$\mathrm{Fe}^{0}$ after reaction with nitrate

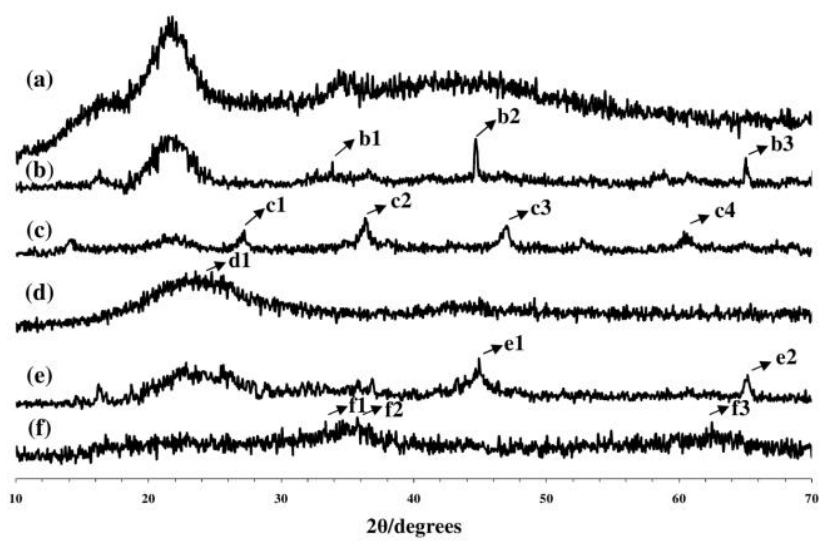

Figure 2. XRD patterns of (a) PC; (b) PC- $\mathrm{Fe}^{0}$ before reacting with nitrate; (c) PC-Fe ${ }^{0}$ after reacting with nitrate; (d) PCAC; (e) PCAC$\mathrm{Fe}^{0}$ before reacting with nitrate; (f) PCAC-Fe ${ }^{0}$ after reacting with nitrate

The main absorption bands of PC were at the following wavelengths (Figure 3a): (1) $1040 \mathrm{~cm}^{-1}$ generated by $\mathrm{OH}$ bending vibration and $\mathrm{C}-\mathrm{O}-\mathrm{C}$ stretching vibration, (2) $1220-1300 \mathrm{~cm}^{-1}$ mainly attributed to the phase combination of $\mathrm{C}-\mathrm{N}$ stretching, $\mathrm{N}-\mathrm{H}$ bending vibrations (amide III region), (3) $1325-1410 \mathrm{~cm}^{-1}$ assigned to the symmetric bending vibration of $\mathrm{CH}_{3}$ and $\mathrm{CH}_{2}$, and the shear-type vibration absorption of $\mathrm{CH}_{3}$ in proteins and 
cellulose (Amir et al., 2004), (4) $1410-1450 \mathrm{~cm}^{-1}$ represented the $\mathrm{C}-\mathrm{O}$ stretching vibration in carboxylate ions (-COO-), (5) 1450-1480, 2850, and $2920 \mathrm{~cm}^{-1}$ represented the symmetric and asymmetric stretching vibration of the $\mathrm{CH}_{2}$ and $\mathrm{CH}_{3}$, (6) $1510-1530 \mathrm{~cm}^{-1}$ associated to the presence of $\mathrm{N}-\mathrm{H}$ and $\mathrm{C}-\mathrm{H}$ bending and stretching vibration (amide II region), (7) the amide I peak appeared at 1610-1650 $\mathrm{cm}^{-1}$ (Deng et al., 2013), (8) 1734 $\mathrm{cm}^{-1}$ assigned to the $\mathrm{C}=\mathrm{O}$ stretching vibration, and (9) $3000-3800 \mathrm{~cm}^{-1}$ attributed to the presence of $-\mathrm{OH}$ and -NH stretching vibration of carbohydrate, cell wall compounds, and proteins. The spectrum of PCAC (Figure 3c) reveals bands centered at $700-900 \mathrm{~cm}^{-1}$ attributed to the aromatic $\mathrm{C}-\mathrm{H}$ stretching vibration. The band centered at $1145 \mathrm{~cm}^{-1}$ can be assigned to the aromatic $\mathrm{CO}-$ stretching vibration. The presence of band at $1560 \mathrm{~cm}^{-1}$ can be assigned to the aromatic $\mathrm{C}=\mathrm{C}$ ring stretching. The peak at $2315 \mathrm{~cm}^{-1}$ was attributed to the $\mathrm{C}=\mathrm{O}$ stretching (Kazemipour et al., 2008). The band centered at $1705 \mathrm{~cm}^{-1}$ was assigned to the aromatic carboxyl $\mathrm{C}=\mathrm{O}$ stretching vibration in ketones or carbonyl group (Tangjuank et al., 2009), while the bands at 2850 and $2920 \mathrm{~cm}^{-1}$ were disappeared. The decreasing of the intensity of the peaks between $3300-3500 \mathrm{~cm}^{-1}$ pointed out the loss of surface-bonded moisture and decomposition of the cellulose-based pine cone structure.

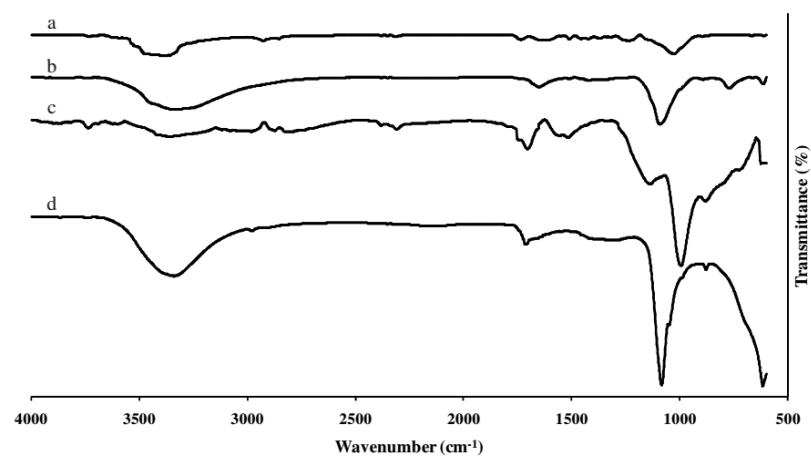

Figure 3. FTIR spectra of (a) PC, (b) PC-Fe ${ }^{0}$, (c) PCAC and (d)PCAC$\mathrm{Fe}^{\mathrm{O}}$

It can be observed that in Figures $3 b$ and $3 d$, several noticeable changes are occurred in the spectrums of $P C-\mathrm{Fe}^{0}$ and PCAC-Fe ${ }^{0}$ in comparison with the spectrums of PC and PCAC. Plant cells are made of polysaccharide, protein, lipid composition, containing carbonyl, hydroxyl, carboxyl, amino and other active sites which could bind with iron ions (Ponder et al., 2000; Macfie and Welbourn,

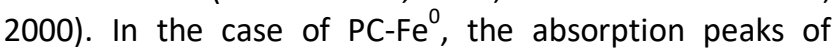
carboxyl (1410-1450 $\mathrm{cm}^{-1}$ ), amide (1220-1300; 1510-1530 and $\left.1610-1650 \mathrm{~cm}^{-1}\right)$, and hydroxyl $\left(3000-3800 \mathrm{~cm}^{-1}\right)$ groups were shifted significantly. Amide absorption bands were characteristics of protein spectra, so it can be reasonably supposed that proteins could chelate with iron ions, which was evidenced by other researchers (Arshadi et al., 2014). The peaks at 2850 and $2920 \mathrm{~cm}^{-1}\left(\mathrm{CH}_{2}\right.$ groups) were weakened in the spectrum of $\mathrm{PC}-\mathrm{Fe}^{0}$. The IR band at $620 \mathrm{~cm}^{-1}$ is related to $\mathrm{Fe}-\mathrm{O}$ stretching vibrations, also the weak band at $780 \mathrm{~cm}^{-1}$ is appeared due to $\mathrm{Fe}-\mathrm{O}-\mathrm{H}$ bending vibrations in goethite (Gotic and Music, 2007). These peaks are only recognized in the spectrum of $\mathrm{PC}-\mathrm{Fe}^{0}$, which is in a good agreement with the XRD pattern (Figure 2b), where the surface of the supported nZVI particles was partially oxidized. Compared to the FTIR spectra of PCAC (Figure $3 c$ ), changes in the adsorption peaks from PCAC-Fe ${ }^{0}$ in Figure $3 \mathrm{~d}$ were observed. On the basis of IR bands (Figure $3 d$ ), strong adsorption peak at $3345 \mathrm{~cm}^{-1}$ (the stretching vibrations of the hydroxyl group) and adsorption peak at $1705 \mathrm{~cm}^{-1}$ (the stretching vibrations of the carboxylic group) are very sensitive to the stabilization of $\mathrm{nZVI}$, and this bands are shifted significantly. A relative decrease in the carboxylic band and an increase in the $\mathrm{OH}$ band were recorded, indicating that these bands were affected due to the iron attachment which was evidenced by other researchers (Chen et al., 2011; Li et al., 2010; Li et al., 2011a). In accordance with achievements by Gotic and Music (2007), the IR band at $618 \mathrm{~cm}^{-1}$ is related to Fe-O stretching vibrations (Gotic and Music, 2007). These results demonstrated that $\mathrm{nZVI}$ particles had been successfully loaded onto PCAC.

\subsection{Effect of the initial $\mathrm{pH}$ and zeta potential}

The effect of $\mathrm{pH}$ on the adsorption of nitrate by the adsorbents was studied over a $\mathrm{pH}$ range of 2-10 (Figure 4). The alteration of the surface charges as a function of $\mathrm{pH}$ (1.5-12.5) was measured in a $10^{-3} \mathrm{M} \mathrm{NaCl}$ background solution (Figure 5). At $\mathrm{pH}<\mathrm{pH}$ value of point of zero charge $\left(\mathrm{pH}_{\mathrm{pzc}}\right)$, the sorbent has the positive surface charge, while at $\mathrm{pH}>\mathrm{pH}_{\mathrm{pzc}}$, the surface charge of the sorbent is negative. It can be seen (Figure 4) that the nitrate removal was highly dependent on the initial $\mathrm{pH}$ of the solution. At higher $\mathrm{pH}$, the competition for active sites by $\mathrm{OH}^{-}$ions and the electrostatic repulsion of anionic nitrate by the negatively charged surface of the PC and PCAC may be resulted in less nitrate adsorption. Nitrate reduction by PCAC-Fe ${ }^{0}$ was observed to be higher compared to other adsorbents. PC-Fe ${ }^{0}$ and PCAC-Fe ${ }^{0}$ are more sensitive to the initial $\mathrm{pH}$ of solution than $\mathrm{PC}$ and PCAC. In the cases of PC- $\mathrm{Fe}^{0}$ and PCAC-Fe ${ }^{0}$, the removal efficiencies have a decreasing trend, when the initial $\mathrm{pH}$ is increased. A plausible explanation is that, at higher $\mathrm{pH}$, $\mathrm{Fe}$ (II) and Fe(III) precipitation was gradually formed which covered the shell of ZVI nanoparticles, and subsequently reduced the degradation of nitrate (Liu et al., 2012). Therefore, in lower $\mathrm{pH}$, the $\operatorname{Re}(\%)$ was increased significantly, and the maximum nitrate removal was occurred at $\mathrm{pH}=2$, which had also been reported in other studies (Kassaeea et al., 2011). The $\mathrm{pH}_{\mathrm{pzc}}$ of PC is 4.5 , while it decreases to 4 for PCAC (Figure 5). This phenomenon displayed that the activation of PC leads to a negatively charged surface of PCAC due to the separation of carboxyl functional groups (Malik et al., 2002). After being modified with $\mathrm{nZVI}$, the $\mathrm{pH}_{\mathrm{pzc}}$ of PC and PCAC have been shifted to 6.8 and 6.45 , respectively. Pure $\mathrm{nZVI}$ has zero point charges in the $\mathrm{pH}$ range 8-9 (Zhang, 2003). In comparison with the $\mathrm{pH}_{\mathrm{pzc}}$ of pure $\mathrm{nZVI}$, the determined $\mathrm{pH}_{\mathrm{pzc}}$ of $\mathrm{PC}-\mathrm{Fe}^{0}$ and PCAC-Fe ${ }^{0}$ samples are lower than that of the pure $\mathrm{nZVI}$, which might 
be due to the introduction of several oxygen-containing functional groups. The $\mathrm{pH}_{\mathrm{pzc}}$ of $\mathrm{PC}-\mathrm{Fe}^{0}$ and $\mathrm{PCAC}-\mathrm{Fe}^{0}$ could propose an advantage for the removal of anions under neutral $\mathrm{pH}$.

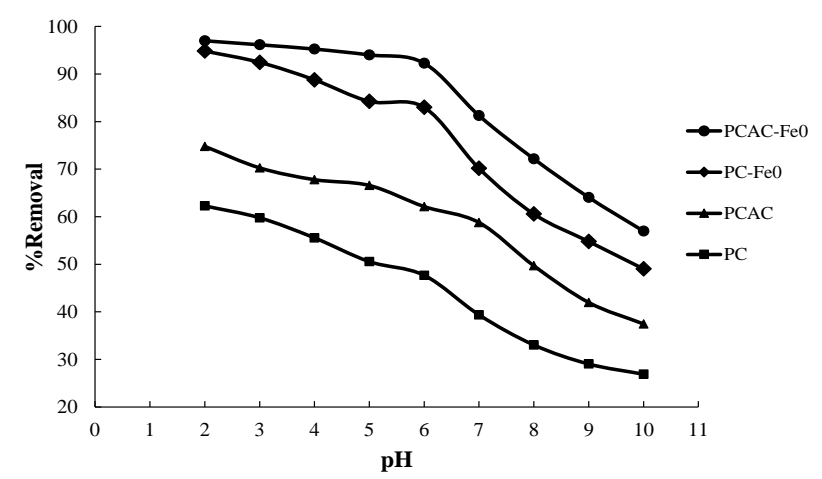

Figure 4. Effect of $\mathrm{pH}$ on the nitrate adsorption by PC, PCAC, PC$\mathrm{Fe}^{0}$ and PCAC-Fe ${ }^{0}\left(\mathrm{C}_{0}=100 \mathrm{mg} \mathrm{L}^{-1}\right.$, sorbent dosage $=10 \mathrm{gL}^{-1}$, $\mathrm{T}=25^{\circ} \mathrm{C}$ )

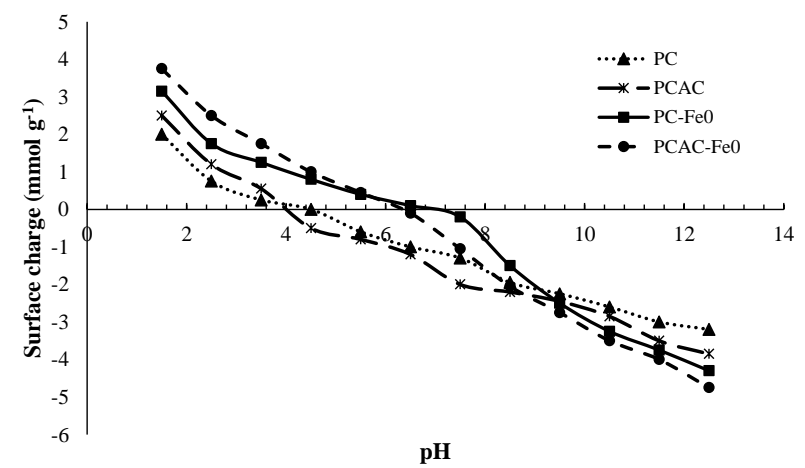

Figure 5. Zeta potential of the sorbents as a function of $\mathrm{pH}$ Experimental error: $\pm 4 \mathrm{mV}$

\subsection{Effect of the sorbent dosage and adsorption temperature}

The initial loadings of adsorbents in the nitrate solution were 2-10 $\left(\mathrm{g} \mathrm{L}^{-1}\right)$. The initial nitrate concentration and the initial $\mathrm{pH}$ value of the solutions were adjusted at $100 \mathrm{mg}$ $\mathrm{L}^{-1}$ ) and 6 , respectively. The removal efficiencies (\%) were increased as the sorbent dosages were increased (Figure 6). As the adsorbents dosages increased from 2 to $6\left(\mathrm{~g} \mathrm{~L}^{-1}\right)$, the removal efficiencies of nitrate ions increased significantly from $58.9 \%$ to $76.1 \%$ and $65.2 \%$ to $87.2 \%$ for PC-Fe ${ }^{0}$ and PCAC-Fe ${ }^{0}$, respectively. This phenomenon can be attributed to the increase in the available adsorption sites and bigger surface area with the increase in the sorbent dosage. With a further increase in sorbent dosages to $10\left(\mathrm{~g} \mathrm{~L}^{-1}\right)$, the nitrate removal is increased slightly to 83 and $92.3 \%$ for $P C-\mathrm{Fe}^{0}$ and $\mathrm{PCAC}-\mathrm{Fe}^{0}$, respectively. This was because of the saturation of the active sites (Shi et al., 2011). Figure 7 demonstrates the effect of adsorption temperature $\left(25-55^{\circ} \mathrm{C}\right)$ on the removal efficiency of nitrate ions $\left(\mathrm{C}_{0}=100 \mathrm{mg} \mathrm{L}^{-1}, \mathrm{pH}=6\right)$. It can be seen from Figure 7 that the removal percentage of nitrate increased with an increase in the adsorption temperature from 25 to $55{ }^{\circ} \mathrm{C}$. This might be because of high temperature is beneficial for the diffusion of nitrate ions to active adsorption sites of adsorbents, which will favor the adsorption of nitrate. Therefore, in higher temperature, the $\operatorname{Re}(\%)$ was increased slightly, and the maximum nitrate removal percentage ( $R e=97 \%)$ was belong to PCAC-Fe ${ }^{0}$ at $\mathrm{T}=55^{\circ} \mathrm{C}$, which is in accordance with the other studies (Song et al., 2016; Tong et al., 2017).

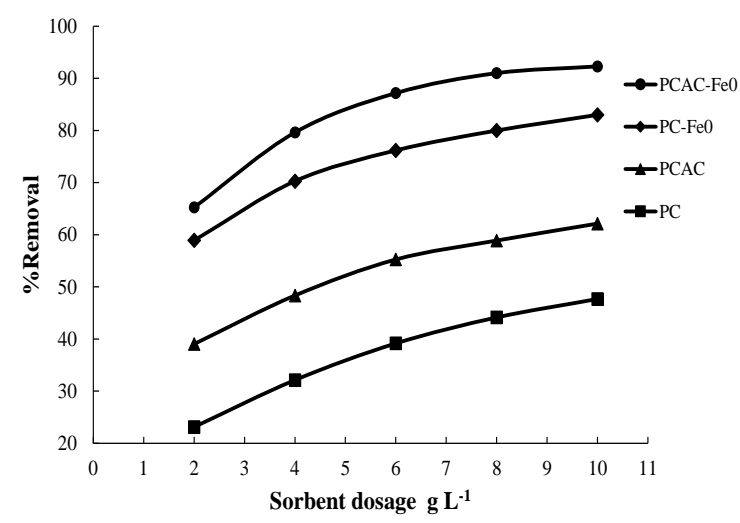

Figure 6. The variation of nitrate adsorption (\%) at different sorbent dosages, $\mathrm{pH}=6, \mathrm{~T}=25^{\circ} \mathrm{C}$

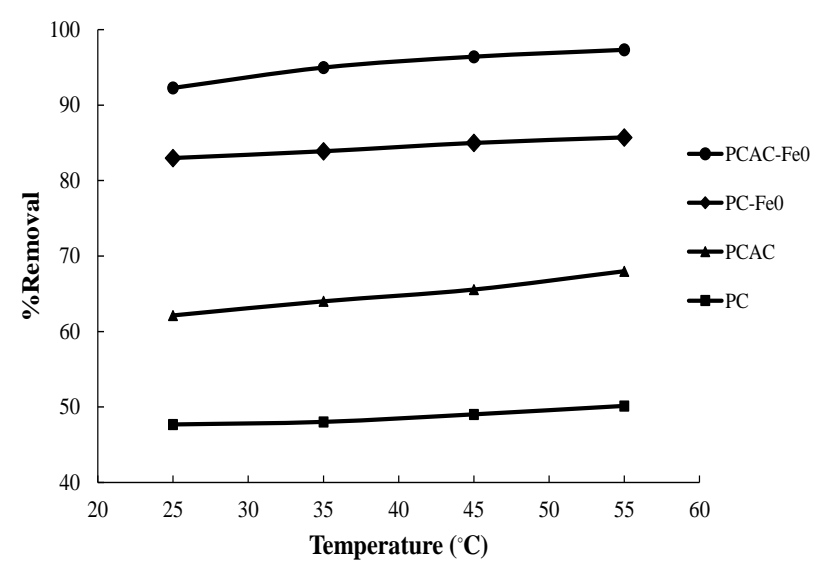

Figure 7. Effect of the adsorption temperature on the nitrate adsorption by PC, PCAC, $\mathrm{PC}-\mathrm{Fe}^{0}$ and PCAC-Fe

3.4. Fate of nitrogen species during nitrate reduction by $P C-\mathrm{Fe}^{0}$ and PCAC-Fe

In the experiments with $\mathrm{PC}-\mathrm{Fe}^{0}$ and $\mathrm{PCAC}-\mathrm{Fe}^{0}$, the concentrations of ammonium, nitrite and nitrate, accumulated in the solution at every time interval, were determined at initial $\mathrm{pH}=6, \mathrm{~T}=25^{\circ} \mathrm{C}$ and $\mathrm{C}_{0}=100 \mathrm{mg} \mathrm{L}^{-1}$. Moreover the mass of ammonium sorbed on $\mathrm{PC}-\mathrm{Fe}^{0}$ and PCAC- $\mathrm{Fe}^{0}$ was measured by extracting with $1.0 \mathrm{M} \mathrm{KCl}$ solution and analyzing the extract solution. The concentrations of nitrogen species during the nitrate reduction by $\mathrm{PC}-\mathrm{Fe}^{0}$ and $\mathrm{PCAC}-\mathrm{Fe}^{0}$ are presented in Figures 8 and 9. At the end of the reaction period, the $\mathrm{NH}_{4}{ }^{+}-\mathrm{N}$ concentrations extracted from PC-Fe ${ }^{0}$ and PCAC$\mathrm{Fe}^{0}$ were accounted for about $72.7 \%$ and $82.1 \%$ of the nitrate reduced, respectively (Figures 8 and 9). The total amount of nitrogen species (TN) in PCAC-Fe ${ }^{0}$ and PC-Fe systems were calculated as the sum of three main 
aqueous nitrogen species (ammonium, nitrate and nitrite) and $\mathrm{NH}_{4}{ }^{+}$extracted from $\mathrm{PCAC}$ and $\mathrm{PC}$, after the reduction reaction was carried out for $24 \mathrm{~h}$. In the case of PCAC-Fe ${ }^{0}$, the $\mathrm{NH}_{4}{ }^{+}$concentration in the solution phase was undetectable at every time interval, indicating that the ammonium produced from nitrate reduction, completely was sorbed on $\mathrm{PCAC}-\mathrm{Fe}^{0} . \mathrm{PC}^{-} \mathrm{Fe}^{0}$ releases little ammonium in the residual solution (about 15.3\% of the nitrate reduced), which is unfavorable. The TN decreased to $11.1 \%$ and $10.6 \%$ of the initial nitrate concentration in $\mathrm{PC}-\mathrm{Fe}^{0}$ and $\mathrm{PCAC}-\mathrm{Fe}^{0}$ systems, respectively. This phenomenon is probably due to the nitrogen conversion from aqueous phase to gas phase. This result agreed with the results of other researchers (Hwang et al., 2011; Shi et al., 2013). It was experimentally proven that the role of $\mathrm{nZVI}$ in the removal of nitrate should be taken part in two major processes: (I) adsorption of nitrate on the nZVI surface; (II) directly participation in the redox reaction (Hwang et al., 2011). This result is pointed out by several authors for the removal of a variety of contaminants using nZVI including: $\mathrm{Cr}$ (VI) (Geng et al., 2009), As(III) (Horzum et al., 2013), $\mathrm{NO}_{3}{ }^{-}$(Hwang et al., 2011; Rodriguez et al., 2009.), $\mathrm{Cu}^{2+}, \mathrm{Co}^{2+}$ (Uzum et al., 2009), pentachlorophenol (Li et al., 2011b), and methyl orange (Chen et al., 2011).

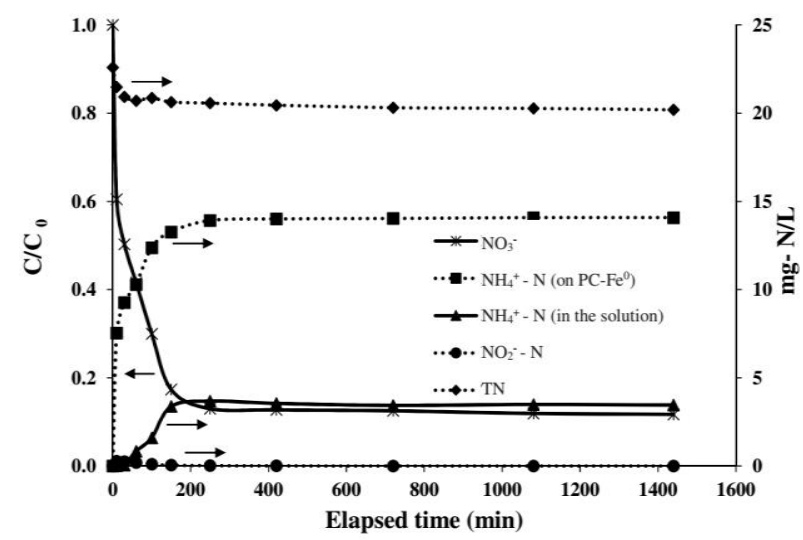

Figure 8. Total nitrogen, ammonium, nitrate and nitrite concentrations in the residual solution and ammonium extracted from $\mathrm{PC}-\mathrm{Fe}^{0}$ after reaction

\subsection{Adsorption kinetics}

The rate of adsorption of nitrate was studied at initial $\mathrm{pH}=6$ and $\mathrm{T}=25^{\circ} \mathrm{C}\left(\mathrm{C}_{0}=100 \mathrm{mg} \mathrm{L}^{-1}\right)$ up to a contact time $24 \mathrm{~h}$. The experimental data were fitted to the kinetic models (Pseudo-first-order, Pseudo second-order and Intra-particle diffusion) by the nonlinear regression analysis using GraphPad Prism tool. Mentioned models are described by Eqs. (4)-(6):

$$
\begin{aligned}
& \text { Pseudo-first-order: } q_{t}=q_{e}\left(1-e^{-k_{1} t}\right) \\
& \text { Pseudo-second-order: } q_{t}=\frac{k_{2} q_{e}^{2} t}{1+k_{2} q_{e}^{2}}
\end{aligned}
$$

Intra-particle diffusion: $\mathrm{q}_{\mathrm{t}}=\mathrm{k}_{\mathrm{i}} \mathrm{t}^{0.5}-\mathrm{C}$
Where $q_{\mathrm{t}}$ and $q_{e}$ are the amounts of the nitrate ions sorbed by adsorbents at time $t(\mathrm{~min})$ and at equilibrium condition ( $\mathrm{mg} \mathrm{g}^{-1}$ ), respectively, and $\mathrm{k}_{1}, \mathrm{k}_{2}, \mathrm{k}_{\mathrm{i}}$ and $\mathrm{C}$ are constants.

The initial adsorption rate, $\mathrm{h},\left(\mathrm{mg} \mathrm{g}^{-1} \mathrm{~min}^{-1}\right)$ is expressed as:

$h=k_{2} q_{e}^{2}$

The application of the kinetic models on experimental results is presented in Figure 10. The kinetic parameters, the correlation coefficients $\left(R^{2}\right)$ and the Standard Error of Estimate (SEE) values for nitrate sorption by adsorbents are given in Table 3. A higher $\mathrm{R}^{2}$ and a lower SEE, indicate a better matching between the experimental (exp) and calculated (cal) nitrate sorption data. In all cases, nitrate adsorption data were fitted well to the Pseudo secondorder model, as indicated by the higher $\mathrm{R}^{2}$ and lower SEE values (Table 3).

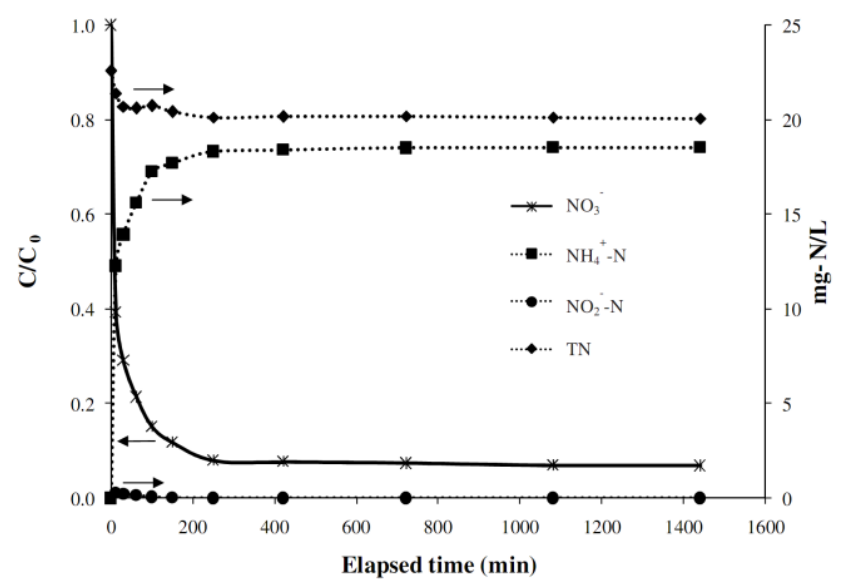

Figure 9. Total nitrogen, nitrate and nitrite concentrations in residual solution and ammonium extracted from $\mathrm{PCAC}-\mathrm{Fe}^{0}$ after reaction

On the other hand, as shown in Table 3, it is noticed that PCAC- $\mathrm{Fe}^{0}$ has the highest initial adsorption rate $(\mathrm{h}=1.4124)$. Thus, $\mathrm{PCAC}-\mathrm{Fe}^{0}$ reacted with nitrate ions much faster than the other samples under the same conditions. Figure 10 shows that the kinetic of the nitrate adsorption includes two phases. Phase I: an initial phase with the rapid rise of the adsorption rate, and Phase II: a gradual adsorption second phase, when adsorption reaches the equilibrium condition. The initial high rate of nitrate removal (Phase I) can be attributed to the most readily available binding sites on the sorbent surfaces (Chatterjee and Woo, 2009). Phase II may be attributed to the slow diffusion of the nitrate from the surface sites into meso-or micro pores. As a result, nitrate uptake occurs both on the surface/pores on the sorbents.

\subsection{Adsorption isotherm}

In order to evaluate the adsorption capacities of the adsorbents for nitrate, sets of experiments were conducted at various initial concentrations (20-320 $\mathrm{mg} \mathrm{L}^{-1}$ ). Equilibrium adsorption data were analyzed using 
Langmuir, Freundlich and Langmuir-Freundlich isotherm models, described by Eqs. (8)-(10):

Langmuir model: $\mathrm{q}_{\mathrm{e}}=\frac{\mathrm{q}_{\mathrm{m}} \mathrm{k}_{\mathrm{l}} \mathrm{C}_{\mathrm{e}}}{1+\mathrm{K}_{\mathrm{l}} \mathrm{C}_{\mathrm{e}}}$

Freundlich model: $\mathrm{q}_{\mathrm{e}}=\mathrm{k}_{\mathrm{F}} \mathrm{C}_{\mathrm{e}}^{\mathrm{n}}$

Langmuir-Freundlich model: $q_{e}=\frac{q_{m} k_{l} C_{e}^{1 / n}}{1+k_{l} C_{e}^{1 / n}}$
Where $\mathrm{q}_{\mathrm{e}}\left(\mathrm{mg} \mathrm{g}^{-1}\right)$ and $\mathrm{C}_{\mathrm{e}}\left(\mathrm{mg} \mathrm{L}^{-1}\right)$ are the amounts of adsorbed nitrate per unit mass of adsorbent at equilibrium condition and equilibrium concentration of nitrate in the solution, respectively. $q_{m}\left(m^{-1}\right)$ is the maximum adsorption capacity. $\mathrm{k}_{\mathrm{l}}\left(\mathrm{L} \mathrm{mg}^{-1}\right), \mathrm{k}_{\mathrm{F}}\left(\mathrm{L} \mathrm{g}^{-1}\right)$ and $n$ are constants. The dimensionless constant separation factor $\left(R_{L}\right)$ can be used to determine whether the adsorption is favorable or not. $R_{L}$ is given by the following equation:

Table 3. Parameter of the kinetic models for the adsorption of nitrate onto PC, PCAC, PC-Fe ${ }^{0}$ and PCAC-Fe

\begin{tabular}{|c|c|c|c|c|c|}
\hline $\begin{array}{c}\text { Adsorbent } \\
\text { Kinetic models }\end{array}$ & & PC & $\mathrm{PC}-\mathrm{Fe}^{0}$ & PCAC & PCAC-Fe ${ }^{0}$ \\
\hline & $q_{e}(\exp )\left(m g ~ g^{-1}\right)$ & 5.154 & 8.827 & 6.467 & 9.314 \\
\hline \multirow{4}{*}{ Pseudo first-order } & $\mathrm{q}_{\mathrm{e}}(\mathrm{cal})\left(\mathrm{mg} \mathrm{g}^{-1}\right)$ & 4.992 & 8.534 & 6.081 & 8.833 \\
\hline & $\mathrm{k}_{\mathrm{I}}\left(\mathrm{L} \mathrm{mg}^{-1}\right)$ & 0.007 & 0.267 & 0.033 & 0.097 \\
\hline & $\mathrm{R}^{2}$ & 0.931 & 0.803 & 0.851 & 0.755 \\
\hline & SEE & 0.429 & 0.867 & 0.521 & 0.698 \\
\hline \multirow{5}{*}{ Pseudo second-order } & $\mathrm{q}_{\mathrm{e}}(\mathrm{cal})\left(\mathrm{mg} \mathrm{g}^{-1}\right)$ & 5.567 & 8.986 & 6.452 & 9.224 \\
\hline & $\mathrm{k}_{2}\left(\mathrm{~L} \mathrm{mg}^{-1}\right)$ & 0.002 & 0.005 & 0.008 & 0.016 \\
\hline & $\mathrm{h}\left(\mathrm{mg} \mathrm{g}^{-1} \mathrm{~min}^{-1}\right)$ & 0.558 & 0.345 & 0.428 & 1.412 \\
\hline & $\mathrm{R}^{2}$ & 0.959 & 0.921 & 0.964 & 0.925 \\
\hline & SEE & 0.327 & 0.547 & 0.254 & 0.324 \\
\hline \multirow{4}{*}{ Intra-particle diffusion } & $\mathrm{k}_{\mathrm{i}}\left(\mathrm{mg} \mathrm{g}^{-1} \mathrm{~min}^{-0.5}\right)$ & 0.121 & 0.123 & 0.087 & 0.072 \\
\hline & $\mathrm{C}$ & -1.330 & -5.261 & -3.862 & -7.202 \\
\hline & $\mathrm{R}^{2}$ & 0.884 & 0.636 & 0.664 & 0.602 \\
\hline & SEE & 0.554 & 0.776 & 0.784 & 0.749 \\
\hline
\end{tabular}
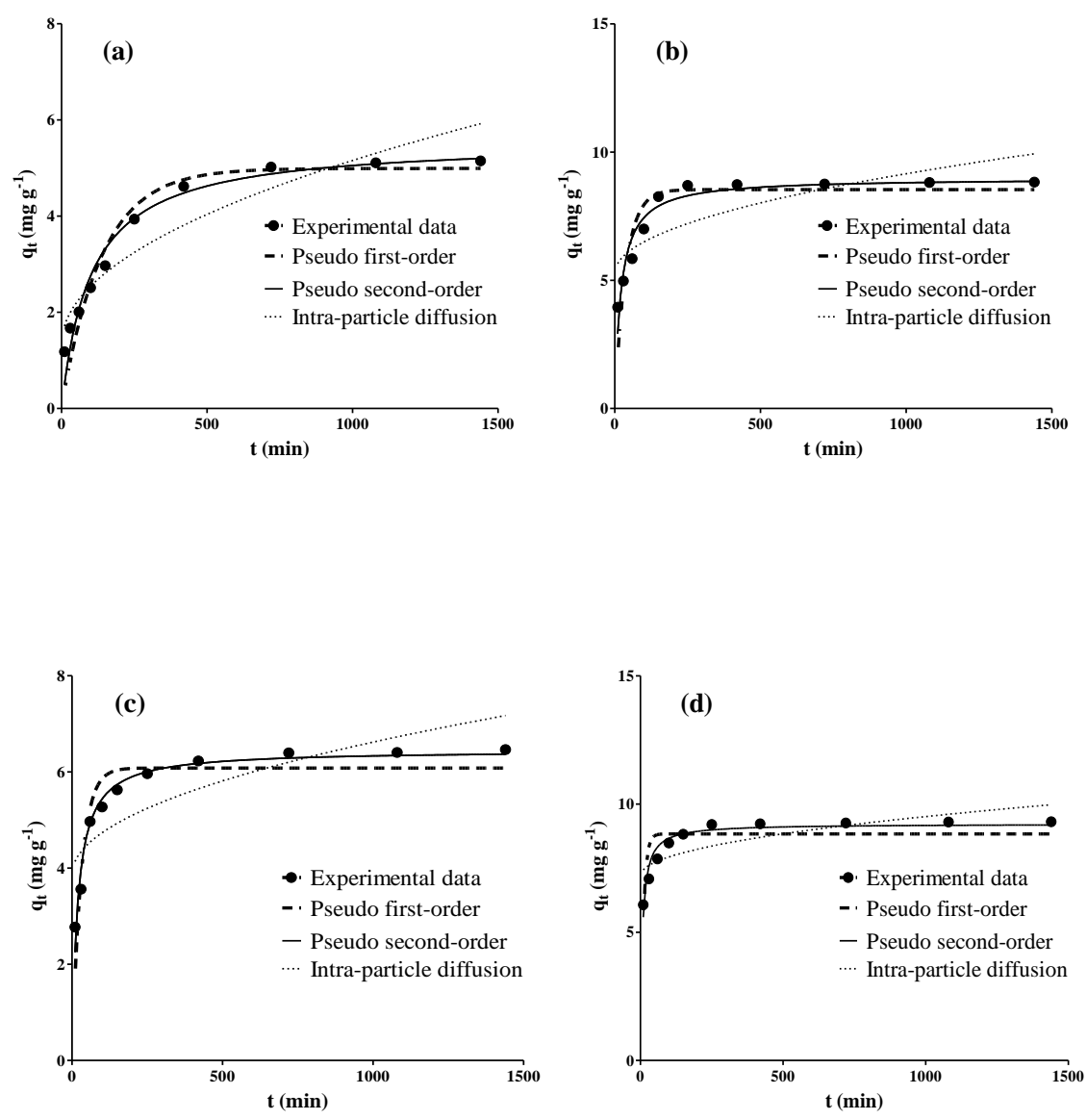

Figure 10. Nitrate adsorption kinetics by (a) PC, (b) PC-Fe ${ }^{0}$, (c) PCAC, and (d) PCAC-Fe ${ }^{0}$ 


$$
\mathrm{R}_{\mathrm{L}}=\frac{1}{1+\mathrm{K}_{\mathrm{l}} \mathrm{C}_{0}}
$$

If $R_{L}>1$, the adsorption is unfavorable; when $R_{L}=0$, the adsorption is irreversible; when $R_{L}=1$, the adsorption is linear; in the range $0<R_{L}<1$, the adsorption is favorable (Ozcan and Ozcan, 2009). The isotherm parameters, $\mathrm{R}^{2}$ and SEE values for nitrate sorption by adsorbents are given in Table 4. The application of the isotherm models on experimental results is presented in Figure 11. In all cases, comparing $\mathrm{R}^{2}$ and SEE values (Table 4) demonstrated that the experimental data were well fitted to the Langmuir-Freundlich model. This means that sorption takes place at the functional group/binding sites on the surface of the sorbents. Figure 11 illustrates that the nitrate adsorption capacities of the all adsorbents is firstly increased with increasing the initial concentration of nitrate, and then they are not changed significantly, indicating that no more sites remain available for adsorption. The maximum adsorption capacities of the PC-Fe ${ }^{0}$ and PCAC-Fe ${ }^{0}$ for nitrate are 18.16 and $22.30\left(\mathrm{mg} \mathrm{g}^{-1}\right)$, respectively. According to the value of $R_{L}$ (Table 4), the adsorption of nitrate onto the all adsorbents is favorable.
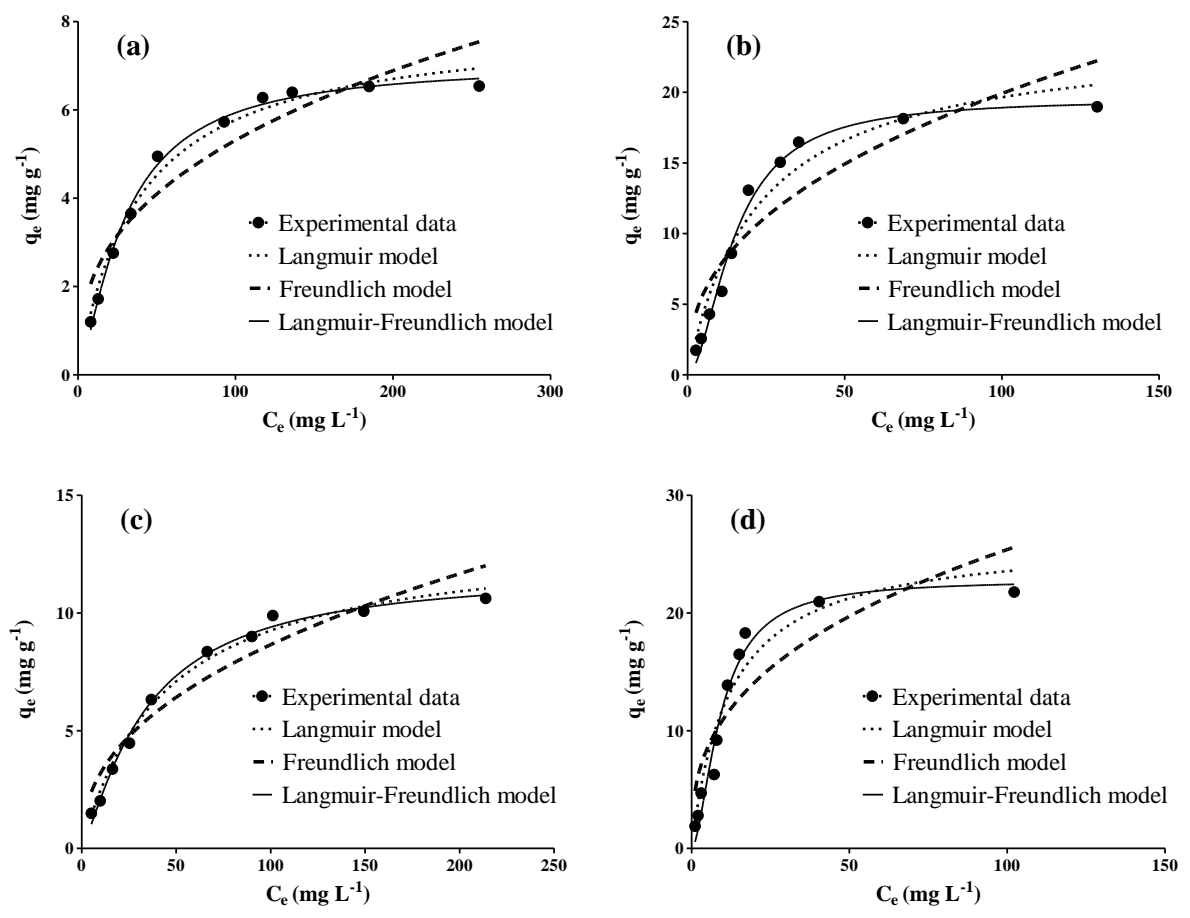

Figure 11. Isotherm plots for the adsorption of nitrate ions onto (a) PC, (b) PC-Fe ${ }^{0}$, (c) PCAC and (d) PCAC-Fe

Table 4. Isotherm parameters for the adsorption of nitrate onto PC, PCAC, $\mathrm{PC}-\mathrm{Fe}^{0}$ and PCAC-Fe

\begin{tabular}{|c|c|c|c|c|c|}
\hline $\begin{array}{c}\text { Adsorbent } \\
\text { Isotherm } \\
\end{array}$ & & PC & $P C-F^{0}$ & PCAC & PCAC-Fe ${ }^{0}$ \\
\hline \multirow{5}{*}{ Langmuir } & $q_{m}\left(\mathrm{mg} \mathrm{g}^{-1}\right)$ & 7.991 & 24.09 & 13.31 & 26.40 \\
\hline & $k_{l}\left(\mathrm{Lmg}^{-1}\right)$ & 0.026 & 0.044 & 0.023 & 0.083 \\
\hline & $R_{L}$ & $0.087-0.752$ & $0.108-0.857$ & $0.102-0.826$ & $0.134-0.936$ \\
\hline & $R^{2}$ & 0.985 & 0.950 & 0.789 & 0.938 \\
\hline & SEE & 0.272 & 0.573 & 0.383 & 0.404 \\
\hline \multirow{4}{*}{ Freundlich } & $k_{f}\left(\mathrm{~L} \mathrm{mg}^{-1}\right)$ & 0.944 & 2.933 & 1.186 & 4.732 \\
\hline & $n$ & 2.665 & 2.404 & 2.317 & 2.742 \\
\hline & $R^{2}$ & 0.897 & 0.830 & 0.925 & 0.798 \\
\hline & SEE & 0.710 & 0.901 & 0.517 & 0.619 \\
\hline \multirow{5}{*}{ Langmuir-Freundlich } & $k_{l}\left(\mathrm{Lmg}^{-1}\right)$ & 0.009 & 0.007 & 0.012 & 0.022 \\
\hline & $q_{m}$ & 6.84 & 18.16 & 11.07 & 22.30 \\
\hline & $n$ & 0.734 & 0.557 & 0.802 & 0.585 \\
\hline & $R^{2}$ & 0.951 & 0.993 & 0.975 & 0.989 \\
\hline & SEE & 0.355 & 0.192 & 0.210 & 0.201 \\
\hline
\end{tabular}




\section{Conclusion}

In this study, nZVI particles supported on raw pine cone $\left(\mathrm{PC}-\mathrm{Fe}^{0}\right)$ and pine cone activated carbon (PCAC-Fe ${ }^{0}$ ) were synthesized, characterized, and applied for the removal of nitrate as a model contaminant from aqueous solution. These novel materials have high specific surface area, and based on the SEM results, nZVI particles are uniformly dispersed across PC and PCAC surface without noticeable aggregation. Natural waste materials are low-cost sorbents, thus, these materials could be effective and promising stabilizers, and dispersants for supporting nZVI particles due to their porous structures. Batch experiments indicated that the nitrate removal efficiency decreased with increasing the initial concentration of nitrate and initial $\mathrm{pH}$ but increased with increasing in the sorbent dosages and temperature. The maximum adsorption capacities of PC- $\mathrm{Fe}^{0}$ and PCAC$\mathrm{Fe}^{0}$ for nitrate were 18.16 and $22.30\left(\mathrm{mg} \mathrm{g}^{-1}\right)$, respectively. Reduction of nitrate using PC-Fe and PCAC- $-\mathrm{Fe}^{0}$ was in accordance with the pseudo second order kinetic model. Moreover, the equilibrium data were fitted well to the Langmuir-Freundlich model. These novel composites are effective at the neutral $\mathrm{pH}$ of the solution $(\mathrm{pH}=6)$ without any $\mathrm{pH}$ adjustment. The nitrogen mass balance calculation revealed that $\mathrm{nZVI}$ particles in $\mathrm{PC}-\mathrm{Fe}^{0}$ and PCAC- $\mathrm{Fe}^{0}$ beads could generally reduce nitrate into ammonium (more than $72 \%$ and $82 \%$ of the reduced nitrate, for $\mathrm{PC}-\mathrm{Fe}^{0}$ and PCAC-Fe ${ }^{0}$, respectively), and nitrite usually occurs as intermediate. Subsequently, PCAC-Fe ${ }^{0}$ absorbs completely un-wanted ammonium due to its high surface area. PC-Fe has less sorption capacity for ammonium in comparison with PCAC-Fe ${ }^{0}$. PC- $\mathrm{Fe}^{0}$ releases little ammonium in the residual solution (about 15.3\% of the reduced nitrate), which is unfavorable. It is concluded that the nitrate removal using $\mathrm{PC}-\mathrm{Fe}^{0}$ and $\mathrm{PCAC}-\mathrm{Fe}^{0}$ consists of three steps: 1) the adsorption of nitrate on the nZVI surface; 2) the redox reaction between $\mathrm{nZVI}$ and nitrate ions; 3) the ammonium absorption by PC-Fe ${ }^{0}$ and PCAC- $\mathrm{Fe}^{0}$. In view of this, PCAC- $\mathrm{Fe}^{0}$, as a low-cost nano-biocomposite, has a great potential to be used as an economical and efficient adsorbent to remove nitrate from water and wastewater.

\section{References}

Allaf R.M., Rivero I.V., Speraman S.S. and Hope-Weeks J. (2011), On the preparation of as-produced and purified singlewalled carbon nanotube samples for standardized X-ray diffraction characterization. Materials Characterization, 62(9), 857-864.

Amir S., Hafidi M., Merlina G., Hamdi H. and Revel J.C. (2004), Elemental analysis, FTIR and 13C-NMR of humic acids from sewage sludge composting. Agronomie, 24(1), 13-18.

APHA W. (1992) Standard Methods for the Examination of Water and Wastewater. Am. Public Health Assoc. Washington, DC.

Arshadi M., Soleymanzadeh M., Salvacion J.W.L. and SalimiVahid F. (2014), Nanoscale zerovalent iron supported on sineguelas waste for the removal of $\mathrm{Pb}(\mathrm{II})$ ions from aqueous solution. Journal of Colloid and Interface Science, 426, 241-251.
Birks L.S. and Friedman H. (1946), Particle size determination from X-ray line broadening. Journal of Applied Physics, 16, 687-692.

Bossa N., Carpenter A., Kumar N., Lannoy C. and Wiesner M. (2017), Cellulose nanocrystal zero-valent iron nanocomposites for groundwater remediation. Environmental Science: Nano, 4(6), 1294-1303.

Chatterjee S. and Woo S.H. (2009), The removal of nitrate from aqueous solutions by chitosan hydrogel beads. Journal of Hazardous Materials, 164, 1012-1018.

Chen Z.X., Jin X.Y., Chen Z. and Megharaj M. (2011), Removal of methyl orange from aqueous solution using bentonitesupported nanoscale zero-valent iron. Journal of Colloid and Interface Science, 363, 601-607.

Deng P.Y., Liu W., Zeng B.Q., Qiu Y.K. and Li L.S. (2013), Sorption of heavy metals from aqueous solution by dehydrated powders of aquatic plants. International Journal of Environmental Science and Technology, 10, 559-566.

Driscoll C., Whitall D., Aber J., Boyer E., Castro M., Cronan C., Goodale C., Groffman P., Hopkinson C., Lambert K., Lawrence G. and Ollinger S. (2003), Nitrogen pollution: sources and consequences in the U.S. Northeast. Environment: Science and Policy for Sustainable Development, 45(7), 8-22.

Geng B., Jin Z., Li T. and Qi X. (2009), Preparation of chitosan-stabilized $\mathrm{Fe}^{0}$ nanoparticles for removal of hexavalent chromium in water. Science of the Total Environment, 407(18), 4994-5000.

Gotic M. and Music S. (2007), Mossbauer, FTIR and FE SEM investigation of iron oxides precipitated from $\mathrm{FeSO}_{4}$ solutions. Journal of Molecular Structure, 834, 445-453.

Haykiri H., Yaman S. and Kucukbayrak S. (2010), Effect of biomass on temperatures of sintering and initial deformation of lignite ash. Fuel, 89, 3063-3068.

Horzum N., Demir M., Nairat M. and Shahwan T. (2013), Chitosan fiber-supported zero-valent iron nanoparticles as a novel sorbent for sequestration of inorganic arsenic. RSC Advances, 3, 7828-7837.

Hou M., Wan H., Liu T., Fan Y., Liu X. and Wang X. (2008), The effect of different divalent cations on the reduction of hexavalent chromium by zerovalent iron. Applied Catalysis B: Environmental, 84(1), 170-175.

Huang D., Xue W., Zeng G., Wan J., Chen G., Huang C., Zhang C., Cheng M. and Xu P. (2016), Immobilization of $C d$ in river sediments by sodium alginate modified nanoscale zerovalent iron: Impact on enzyme activities and microbial community diversity. Water Research, 106, 15-25.

Hwang Y.H., Kim D.G. and Shin H.S. (2011), Mechanism study of nitrate reduction by nano zero valent iron. Journal of Hazardous Materials, 185, 1513-1521.

Joo S.H. and Zhao D. (2008), Destruction of lindane and atrazine using stabilized iron nanoparticles under aerobic and anaerobic conditions: Effects of catalyst and stabilizer. Chemosphere, 70, 418-425.

Kassaee M.Z., Motamedi E., Mikhak A. and Rahnemaie R. (2011), Nitrate removal from water using iron nanoparticles produced by arc discharge vs. reduction. Chemical Engineering Journal, 166, 490-495.

Kazemipour M., Ansari M., Tajrobehkar S., Majdzadeh M. and Reihani-Kermani H. (2008), Removal of lead, cadmium, 
zinc, and copper from industrial wastewater by carbon developed from walnut, hazelnut, almond, pistachio shell, and apricot stone. Journal of Hazardous Materials, 150, 322-327.

Keeney D.R. and Nelson D.W. (1982) Nitrogen Inorganic Forms, Methods of Soil Analysis, Part 2. second ed. SSSA. Madison, Agronomy ASA, pp. 643-698.

Kim H., Kapwn D., Mayer B., Lee J., Hyun Y. and Lee K. (2015), Identifying the sources of nitrate contamination of groundwater in an agricultural area (Haean basin, Korea) using isotope and microbial community analyses. Science of the Total Environment, 533, 566-575.

Li S., Wu P., Li H., Zhu N., Li P., Wu J., Wang X. and Dang Z. (2010), Synthesis and characterization of organomontmorillonite supported iron nanoparticles. Applied Clay Science, 50, 330-338.

Li Y., Li T. and Jin Z. (2011a), Stabilization of $\mathrm{Fe}^{0}$ nanoparticles with silica fume for enhanced transport and remediation of hexavalent chromium in water and soil. Journal of Environmental Sciences, 23(7), 1211-1218.

Li Y., Zhang Y., Li J. and Zheng X. (2011b), Enhanced removal of pentachlorophenol by a novel composite: Nanoscale zero valent iron immobilized on organobentonite. Environmental Pollution, 159, 3744-3749.

Lin Y.T., Weng C.H. and Chen F.Y. (2008), Effective removal of AB24 dye by nano/micro-size zero-valent iron. Separation and Purification Technology, 64, 26-30.

Liu T., Wang Z.L., Zhao L. and Yang X. (2012), Enhanced chitosan/ $/ \mathrm{Fe}^{0}$-nanoparticles beads for hexavalent chromium removal from wastewater. Chemical Engineering Journal, 189-190, 196-202.

Lomnicki S. and Dellinger B. (2003), Development of supported iron oxide catalyst for destruction of PCDD/F. Environmental Science and Technology, 37, 4254-4260.

Macfie S.M. and Welbourn P.M. (2000), The cell wall as a barrier to uptake of metal ions in the unicellular green alga Chlamydomonas reinhardtii (Chlorophyceae). Archives of Environmental Contamination and Toxicology, 39(4), 413419.

Malik D.J., Streiko V., Streat M. and Puizy A.M. (2002), Characterisation of novel modified active carbons and marine algal biomass for the selective adsorption of lead. Water Research, 36, 1527-1538.

Mukherjee R., Kumar R., Sinha A., Lama Y. and Saha A. (2016), A review on synthesis, characterization, and applications of nano zero valent iron (nZVI) for environmental remediation. Critical Reviews in Environmental Science and Technology, 46(5), 443-466.

Ozcan S.A. and Ozcan O. (2009), Adsorption of lead(II) ions onto 8-hydroxy quinoline-immobilized bentonite. Journal of Hazardous Materials, 161, 499-509.

Pan G., Li L., Zhao D. and Chen H. (2010), Immobilization of nonpoint phosphorus using stabilized magnetite nanoparticles with enhanced transportability and reactivity in soils. Environmental Pollution, 158, 35-40.

Ponder S.M., Darab J.G. and Mallouk T.E. (2000), Remediation of $\mathrm{Cr}$ (IV) and $\mathrm{Pb}$ (II) aqueous solutions using supported,nanoscale zero-valent iron. Environmental Science and Technology, 34, 2564-2569.
Rodriguez J.M., Garcia F., Garcia A., Gomez C. and Vereda C. (2009.), Kinetics of the chemical reduction of nitrate by zerovalent iron. Chemosphere, 74, 804-809.

Shi J., Yi S., He H., Lomg C. and Li A. (2013), Preparation of nanoscale zero-valent iron supported on chelating resin with nitrogen donor atoms for simultaneous reduction of $\mathrm{P}^{2} b^{2+}$ and $\mathrm{NO}_{3}{ }^{-}$. Chemical Engineering Journal, 230, 166-171.

Shi L., Zhang X. and Chen Z.L. (2011), Removal of Cr (VI) from wastewater using bentonite-supported nanoscale zerovalent iron. Water Research, 45, 886-892.

Song W., Gao B., Wang F., Xue N., Sun S., Song W. and Jia R. (2016), Adsorption of nitrate from aqueous solution by magnetic amine-crosslinked biopolymer based corn stalk and its chemical regeneration property. Journal of Hazardous Materials, 304, 280-290.

Sun S. and Zeng H. (2002), Size-Controlled synthesis of magnetite nano-particles. Journal of the American Chemical Society, 124, 8240-8205.

Tada K., Kawaguchi T. and Shimazu K. (2004), High electrocatalytic performance of $\mathrm{Pd} / \mathrm{Sn} / \mathrm{Au}$ electrodes for nitrate reduction. Journal of Electroanalytical Chemistry, 572, 93-99.

Tangjuank S., Insuk N., Tontrakoon J. and Udeye V. (2009), Adsorption of Lead(II) and Cadmium(II) ions from aqueous solutions by adsorption on activated carbon prepared from cashew nut. World Academy of Science, Engineering and Technology, 3, 4-28.

Tong X., Yang Z., Xu P., Li Y. and Niu X. (2017), Nitrate adsorption from aqueous solutions by calcined ternary $\mathrm{Mg}$-Al-Fe hydrotalcite. Water Science and Technology, 75(10), 21942203.

Uzum C., Shahwan T., Eroglu A.E., Hallam K.R. and Scott T. (2009), Synthesis and characterization of kaolinite-supported zero-valent iron nanoparticles and their application for the removal of aqueous $\mathrm{Cu}^{2+}$ and $\mathrm{Co}^{2+}$ ions. Applied Clay Science, 43, 172-181.

Wang W., Zhou M., Mao Q., Yue J. and Wang X. (2010), Novel NaY zeolite-supported nanoscale zero-valent iron as an efficient heterogeneous Fenton catalyst. Catalysis Communications, 11, 937-941.

Wang X., Chen C., Liu H. and Ma J. (2008), Preparation and characterization of PAA/PVDF membrane-immobilized Pd/Fe nanoparticles for dechlorination of trichloroacetic acid. Water Research, 42, 4656-4664.

Wang X., Wang P., Ma J., Liu H. and Ning P. (2015), Synthesis, characterization, and reactivity of cellulose modified nano zero-valent iron for dye discoloration. Applied Surface Science, 345, 57-66.

Zhang W.X. (2003), Nanoscale iron particles for environmental remediation: an overview. Journal of Nanoparticle Research, 5, 323-332.

Zhao X., Liu W., Cai Z., Han B., Qian T. and Zhao D. (2016), An overview of preparation and applications of stabilized zero-valent iron nanoparticles for soil and groundwater remediation. Water Research, 100, 245-266. 